\title{
Chemistry and Pharmacology of the Piperidine-Based Analogues of Cocaine. Identification of Potent DAT Inhibitors Lacking the Tropane Skeleton
}

\author{
Alan P. Kozikowski, ${ }^{, \dagger}$ Gian Luca Araldi, ${ }^{\dagger}$ J ohn Boja, ${ }^{\ddagger}$ William M. Meil, ${ }^{\ddagger}$ Kenneth M. J ohnson, ${ }^{\S}$ \\ J udith L. Flippen-Anderson," Clifford George," and Eddine Saiah ${ }^{\perp}$ \\ Drug Discovery Program, Institute of Cognitive and Computational Sciences, Georgetown University Medical Center, \\ 3970 Reservoir Road, NW, Washington, D.C. 20007-2197, Department of Pharmacology, NEOU COM, Rootstown, Ohio 44272, \\ Department of Pharmacology and Toxicology, University of Texas Medical Branch, Galveston, Texas 77555-1031, Laboratory \\ for the Structure of Matter, Code 6030, Naval Research Laboratory, 4555 Overlook SW, Washington, D.C. 20375-5000, and \\ Helios Pharmaceuticals, 9800 Bluegrass Parkway, Louisville, Kentucky 40299
}

Received J anuary 15, 1998

To discover agents that might be useful in the treatment of cocaine abuse, we have chosen to reexplore a class of molecules that was first reported by Clarke et al. in 1973 and that was and shown to lack locomotor stimulatory activity in mice. These compounds are piperidine3-carboxylic acid esters bearing a 4-chlorophenyl group in position 4, and as such, these structures may be viewed as truncated versions of the WIN series compounds, i.e., they lack the two-carbon bridge of the tropanes. All members of this class were synthesized starting from arecoline hydrobromide and obtained in optically pure form through resolution methods using either (+)- or (-)-dibenzoyltartaric acid. Interestingly, we have found that these piperidines do, in fact, exhibit substantial affinity in both WIN 35,428 binding at the dopamine transporter and in the inhibition of $\left[{ }^{3} \mathrm{H}\right]$ dopamine uptake. Of all of the compounds synthesized, the 3-n-propyl derivative (-)-9 was found to be the most potent with a binding affinity of 3 $\mathrm{nM}$. This simple piperidine is thus 33 -fold more potent than cocaine in binding affinity and 29-fold more potent in its inhibition of dopamine uptake. Although no efforts have presently been made to "optimize" binding affinity at the DAT, the substantive activity found for the n-propyl derivative (-)-9 is remarkable; the compound is only about 10-fold less active than the best of the high-affinity tropanes of the WIN series. As a further point of interest, it was found that the cis-disubstituted pi peridine (-)-3 is only about 2-fold more potent than its trans isomer (+)-11. This result stands in sharp contrast to the data reported for the tropane series, for the epimerization of the substituent at C-2 from $\beta$ to $\alpha$ has been reported to result in a lowering of activity by 30-200-fold. This smaller spread in binding affinities for the piperidines may reflect the smaller size of these molecules relative to the tropanes, which allows both the cis and the trans isomers to adjust themselves to the binding site on the DAT. Our present demonstration that these piperidine structures do, in fact, possess significant DAT activity, taken together with their reported lack of locomotor activity, provides a compelling argument for exploring this class of molecules further in animal behavioral experiments. The present work thus broadens the scope of structures that may be considered as lead structures in the search for cocaine abuse medications.

\section{Introduction}

It is clear that immediate therapies are needed for the treatment of cocaine abuse worldwide. ${ }^{1}$ It has been estimated, for example, that there are at present over 7 million cocaine abusers in the US alone and that approximately one-third of these users are consistent or hard core users. Undoubtedly cocaine abuse has a tremendous negative impact on our society, for the crime costs associated with cocaine abuse alone amount to nearly 50 billion dollars per year.

To develop agents that might find use in the treatment of cocaine abuse, it will probably be best to identify compounds that possess the ability to mimic partially the effects of cocaine, thereby helping to maintain indi-

\footnotetext{
† Georgetown University Medical Center.

₹ NEOUCOM.

$\S$ University of Texas Medical Branch.

"Naval Research Laboratory.

$\perp$ Helios Pharmaceuticals.
}

viduals in treatment programs while slowly withdrawing them from cocaine. Basically, what may be needed for cocaine abuse treatment is the pharmacological equivalent of methadone, a drug widely used in the treatment of opiate abuse. ${ }^{2}$ In pursuit of a methadone type of approach, we need to identify a partial agonist of cocaine, a substance that elicits some of the same effects in the user as cocaine itself, but without causing the same degree of euphoria. This partial agonist approach constitutes one possible direction to follow in the discovery of a drug for maintenance of individuals in treatment programs.

In experiments carried out by us we have shown that $\mathrm{N}$-ethylmaleimide was capable of inhibiting about $95 \%$ of the specific binding of $\left[{ }^{3} \mathrm{H}\right]$ mazindol, and that the effect of $10 \mathrm{mM} \mathrm{N}$-ethylmaleimide was completely prevented by $10 \mu \mathrm{M}$ cocaine, while neither $300 \mu \mathrm{M}$ dopamine nor d-amphetamine afforded any significant protection. $^{3}$ Furthermore, a recent study of the struc- 
ture of the dopamine transporter revealed that aspartate and serine residues lying within the first and seventh hydrophobic putative membrane spanning regions were critical for dopamine uptake, but less so for [ $\left.{ }^{3} \mathrm{H}\right] \mathrm{CFT}$ (WIN-35428) binding. ${ }^{4}$ For example, replacement of the serine residues at positions 356 and 359 in the seventh hydrophobic region by alanine or glycine reduced $\left[{ }^{3} \mathrm{H}\right] \mathrm{DA}$ uptake, whereas $\left[{ }^{3} \mathrm{H}\right] \mathrm{CFT}(\mathrm{WIN}-35428)$ binding was less affected. More recent experiments with DA and NE transporter chimeras show that transmembrane domains 6-8 determine cocaine binding while domains 9-12 plus the carboxy tail are responsible for DA binding affinity. ${ }^{5}$ Thus, these data support the hypothesis that a significant portion of the cocaine binding domain on the dopamine transporter is distinct from that of either dopamine or amphetamine. This distinction may be sufficient to allow properly designed drugs to prevent cocaine binding without inhibiting dopamine uptake.

In view of the above notion, we were led to investigate the biological activity of compounds that can be considered to be truncated analogues of cocaine or more precisely truncated analogues of the WIN series of compounds. These compounds, as diagrammed below, are piperidines that lack cocaine's two-carbon bridge. Prior to our own work, several racemic pi peridine anal ogues were investigated by researchers at Sterling Winthrop laboratories and were shown to lack locomotor stimulant activity when tested in mice. ${ }^{6}$ Given the reduced molecular size of these pi peridines rel ative to the tropanes themselves, and the fact that they still embody cocaine's "pharmacophoric elements", we were encouraged to explore their biology. Below we detail the chemical synthesis of these materials in optically pure form and provide details of their in vitro pharmacology.

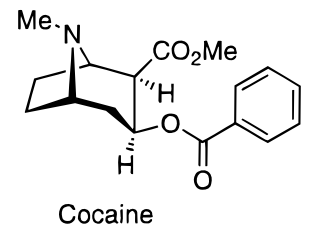

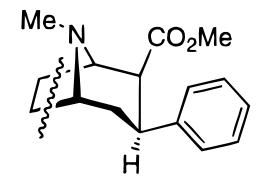

WIN series

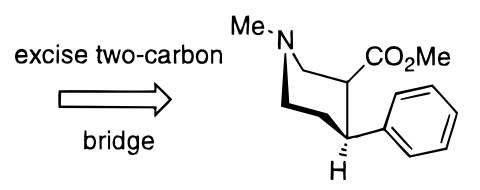

Piperidine Analog

\section{Chemical Synthesis}

The racemic piperidines $\mathbf{1}$ and $\mathbf{2}$ were prepared starting from arecoline hydrobromide using chemistry similar to that reported by Plati in his synthesis of the unsubstituted phenyl bearing piperidine analogues. ${ }^{7}$ Thus, the hydrobromide salt of arecol ine was converted to its free base by sodium bicarbonate, and this intermediate was subjected to a Grignard reaction using ( $p$ chlorophenyl)magnesium bromide. A mixture of the cisand trans-disubstituted piperidines $\mathbf{1}$ and $\mathbf{2}$ was produced in a 75/25 ratio. The cis derivative was obtained by crystallization of the crude material using EtOAc/ hexane as solvent. The racemic trans piperidine was

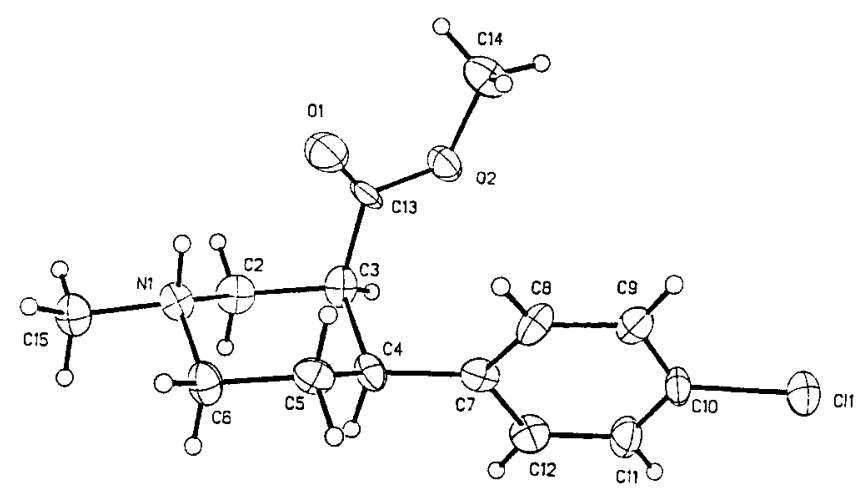

Figure 1. ORTEP drawing of (-)-3 which establishes its absolute stereochemistry.

readily obtained by flash chromatography of the mother liquor. We have been able to efficiently resolve the racemic cis-configured ester by use of $(+)$ - and (-)dibenzoyltartaric acid to provide the pure enantiomers $(-)-3$ and $(+)-4{ }^{8}$ An X-ray structure determination of the salt formed from (-)-dibenzoyltartaric acid and $\mathbf{1}$ has been used to determine the absol ute stereochemistry of (-)-3 which is depicted in Figure 1 . As is apparent, the absolute stereochemistry of the (-)-isomer corresponds to that found in the WIN series of structures. The optically pure $(+)$ - and (-)-cis esters have been converted to their respective alcohols $(-)-5$ and $(+)-6$ by LAH reduction and these in turn to their acetate derivatives (-)-7 and ( + )-8 by acetylation in the presence of pyridine.

To explore the effect of having a less polar, nonhydrolyzable group at the $\mathrm{C}-3$ position, we have in several cases transformed the ester group of the piperidines to an n-propyl substituent. ${ }^{9}$ In the case of (-)-3, this chemistry was accomplished by converting ester to aldehyde by way of the alcohol intermediate 5, performing a Wittig reaction, and last carrying out a catalytic hydrogenation reaction to provide (-)-9. In one case, to examine the contribution of the p-chloro substituent to binding affinity, we have converted the cis piperidine $(-)-\mathbf{3}$ to the dechloro product ( -$)-\mathbf{1 0}$ by hydrogenolysis over palladium on charcoal. Details of the reaction methods can be found in Scheme 1 .

In view of the fact that the biologically more interesting compound is the trans isomer $( \pm)$-2 (vide infra), efforts have been made to resolve this compound as well. Due to the fact that we could not obtain good crystals from ( \pm )-2 and dibenzoyltartaric acid, we have instead carried out a base-catalyzed epimerization reaction on $(-)-3$ and $(+)-4$ to obtain the optically pure transconfigured products $(+)-\mathbf{1 1}$ and $(-)-\mathbf{1 2}$ (Scheme 2 ). The more active isomer (+)-11 was also converted, as described for the cis isomer, to its alcohol $(+)$-13, acetate $(+)$-14, and n-propyl derivative (+)-15. Details of the chemistry are provided in Scheme 2.

\section{In Vitro Biochemical Pharmacology}

The racemic and optically pure pi peridine derivatives 1-15 were tested for their ability to displace $\left[{ }^{3} \mathrm{H}\right] \mathrm{WI} \mathrm{N}$ 35428 binding from rat striatal membranes and to inhibit the high-affinity uptake of $\left[{ }^{3} \mathrm{H}\right]$ dopamine into rat striatal nerve endings (synaptosomes) in accordance with protocols previously described by Boja et al. ${ }^{10}$ The results of these assays are provided in Table 1 . As is 
Scheme 1. Synthesis of the Cis-Disubstituted Piperidine Analogues

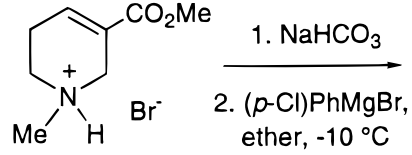

Arecoline hydrobromide

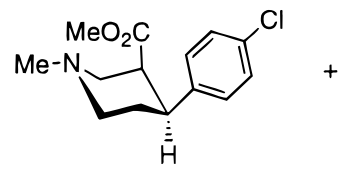

1, cis isomer (racemic)

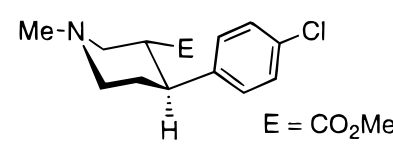

2, trans isomer (racemic)

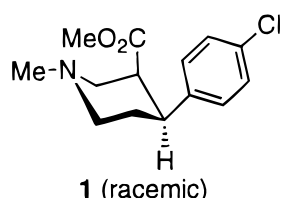

(+)- or (-)-dibenzoyl-

tartaric acid, $\mathrm{MeOH}$

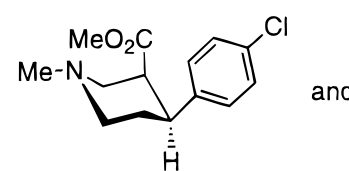

$(-)-3,[\alpha]_{D}=-56^{\circ}$

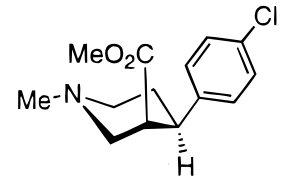

$(+)-4,[\alpha]_{D}=+56^{\circ}$

LAH, THF, RT, $1 \mathrm{~h}$

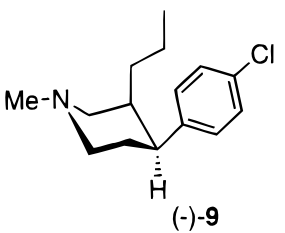

$(-)-9$
1. $(\mathrm{COCl})_{2}$, TEA, DMSO, $\mathrm{CH}_{2} \mathrm{Cl}_{2}$ 2. $\mathrm{Ph}_{3} \mathrm{P}^{+} \mathrm{EtBr}, n$-BuLi, THF 3. $\mathrm{H}_{2}(1 \mathrm{~atm}), 5 \% \mathrm{Pt} / \mathrm{C}$, cyclohexane<smiles>C1CCCCC1</smiles><smiles>CN1CC(CO)CC1c1ccc(Cl)cc1</smiles>

$(-)-5$<smiles>CC(=O)OC1CC2CCCC(C1)C2c1ccc(Cl)cc1</smiles>

$(-)-7$
$(+)-6$

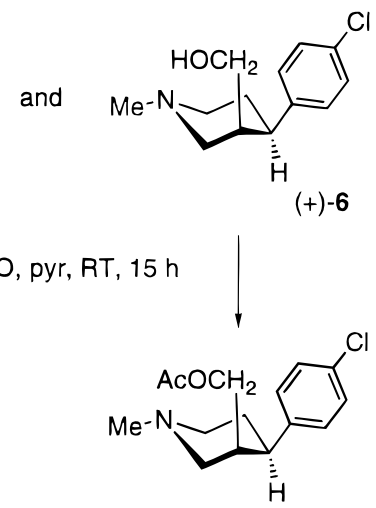

$(+)-8$

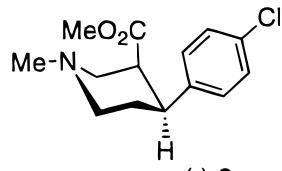

$(-)-3$

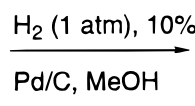

$\mathrm{Pd} / \mathrm{C}, \mathrm{MeOH}$

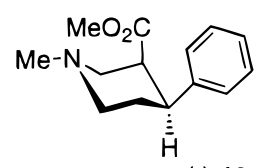

$(-)-10$ apparent from this table, the optically pure (-)-enantiomer $\mathbf{3}$ is about 54-fold more potent than its (+)-isomer 4 in WIN-35428 binding and about 4-fold more potent than cocaine. The racemic piperidine $( \pm)-\mathbf{1}$ is, as expected, about 2 -fold less potent than (-)-3. Reduction of the ester group of $\mathbf{3}$ to alcohol causes a 3-fold drop in potency, whereas the same transformation in the case of (+)-4 leads to an improvement in binding affinity. Acylation of the hydroxyl group of $(-)-5$ to yield (-)-7 leads to an increase in potency; the acetate is only 2 -fold less potent than the ester from which it is derived. Curiously, acylation of (+)-6 to afford ( + )-8 leads to a 2 -fold decrease in binding affinity. Of all of the compounds synthesized, the n-propyl derivative (-)-9 is the most potent with a binding affinity of $3 \mathrm{nM}$. This simple piperidine is thus 33-fold more potent than cocaine in binding affinity and 29-fold more potent in the inhibition of dopamine uptake. As to be expected based upon previous work, ${ }^{14}$ the $\mathrm{p}$-chloro substituent does add to compound potency, as its removal, as in the case of (-)10, causes a 31-fold drop in potency.

Interestingly, the racemic trans isomer $( \pm)-\mathbf{2}$ is only 2 -fold less potent than cocaine. The activity of its eutomer (the more active isomer) should therefore be essentially comparable to that of cocaine. Indeed, the measured binding affinity of (+)-11 is $57 \mathrm{nM}$, while its activity in DA uptake inhibition is $35 \mathrm{nM}$. Its enantiomer (-)-12 is considerably less potent with a binding affinity of $653 \mathrm{nM}$. Reduction of (+)-11 to its alcohol $(+)-13$ leads to a drop in binding affinity ( $\sim 4$-fold), with a further drop in potency being observed upon acylation of the alcohol to give (+)-14. Again, as found in the cis series, the transformation of the ester group to the more hydrophobic n-propyl group results in a 3.8-fold increase in binding affinity.

\section{Discussion}

As is apparent form the data presented, these piperidine analogues of the WIN series structures are potent compounds both in displacing WIN 35,428 binding and in inhibiting DA uptake at the dopamine transporter. Although no efforts have presently been made to "optimize" binding affinity at the DAT, the substantive activity found for the n-propyl derivative (-)-9 of $3 \mathrm{nM}$ is remarkable; the compound is only about 10-fold less active than the best of the high-affinity tropanes in the WIN series. As mentioned in the Introduction, several structurally related piperidines had first been reported by Clarke et al. in 1973 and tested for their ability to increase locomotor activity in 
Scheme 2. Synthesis of the Trans-Disubstituted Piperidine Analogues<smiles>CC(C)[C@H]1CN(C)C[C@H]1c1ccc(Cl)cc1</smiles>

$\mathrm{NaOMe}, \mathrm{MeOH}$ reflux, $24 \mathrm{~h}$

$\mathrm{NaOMe}, \mathrm{MeOH}$

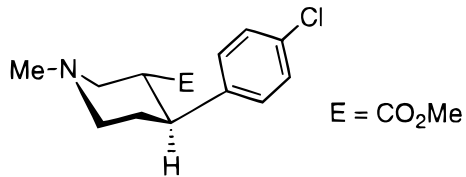

$(+)-11 ;[\alpha]_{D}=+46^{\circ}$<smiles>COCC1(CO)CN(C)C[C@H]1c1ccc(Cl)cc1</smiles>

$(-)-4$

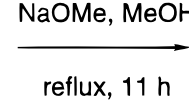

$(+)-11$
$\underset{\mathrm{RT}, 15 \mathrm{hr}}{\stackrel{\mathrm{Ac}_{2} \mathrm{O}, \mathrm{pyr}}{\longrightarrow}}$

$(+)-13$<smiles>CCC(CCN(C)C)c1ccc(Cl)cc1</smiles>

$(-)-12 ;[\alpha]_{D}=-50^{\circ}$

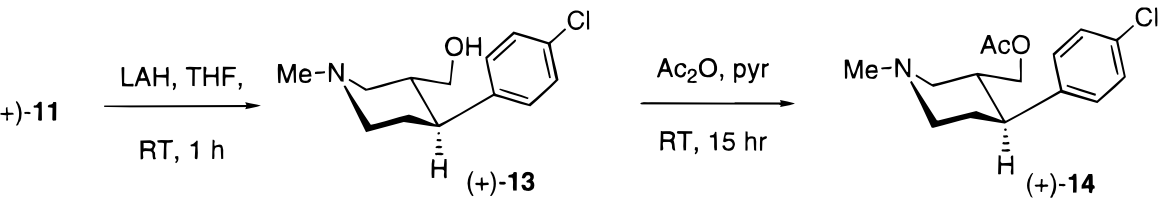

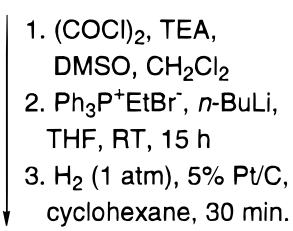<smiles>CCC1CN(C)C[C@H]1c1ccc(Cl)cc1</smiles>

$(+)-15$

Table 1. IC $\mathrm{C}_{50}$ Values and Hill Coefficients for the Piperidine Analogues in $\left[{ }^{3} \mathrm{H}\right] \mathrm{WIN} 35,428$ Binding and in the Inhibition of $\left[{ }^{3} \mathrm{H}\right]$ Dopamine U ptake

\begin{tabular}{|c|c|c|c|c|c|c|}
\hline compd & $\mathrm{R}$ & $x$ & $\begin{array}{c}\mathrm{IC}_{50}(\mathrm{nM})\left[{ }^{3} \mathrm{H}\right] \mathrm{WIN} \\
35,428 \text { binding }\end{array}$ & Hill coeff & $\begin{array}{c}I \mathrm{C}_{50}(\mathrm{nM})\left[{ }^{3} \mathrm{H}\right] \text { dopamine } \\
\text { uptake }\end{array}$ & Hill coeff \\
\hline cocaine & & & $102 \pm 9$ & $0.87 \pm 0.03$ & $239 \pm 1$ & $1.06 \pm 0.04$ \\
\hline$( \pm)-\mathbf{1}$ & $\beta-\mathrm{CO}_{2} \mathrm{Me}$ & $\mathrm{Cl}$ & $53.7 \pm 1.9$ & $0.91 \pm 0.01$ & $37.8 \pm 7.9$ & $1.04 \pm 0.07$ \\
\hline$( \pm)-\mathbf{2}$ & $\alpha-\mathrm{CO}_{2} \mathrm{Me}$ & $\mathrm{Cl}$ & $197 \pm 8$ & $0.91 \pm 0.01$ & & \\
\hline$(-)-\mathbf{3}$ & $\beta-\mathrm{CO}_{2} \mathrm{Me}$ & $\mathrm{Cl}$ & $24.8 \pm 1.6$ & $0.78 \pm 0.04$ & $85.2 \pm 2.6$ & $0.94 \pm 0.01$ \\
\hline$(+)-4$ & $\beta-\mathrm{CO}_{2} \mathrm{Me}$ & $\mathrm{Cl}$ & $1360 \pm 125$ & $0.81 \pm 0.05$ & $5090 \pm 172$ & $0.95 \pm 0.11$ \\
\hline$(-)-5$ & $\beta-\mathrm{CH}_{2} \mathrm{OH}$ & $\mathrm{Cl}$ & $75.3 \pm 6.2$ & $0.56 \pm 0.05$ & $49.0 \pm 3.0$ & $1.04 \pm 0.01$ \\
\hline$(+)-6$ & $\beta-\mathrm{CH}_{2} \mathrm{OH}$ & $\mathrm{Cl}$ & $442 \pm 32$ & $0.66 \pm 0.02$ & & \\
\hline$(-)-7$ & $\beta-\mathrm{CH}_{2} \mathrm{OAC}$ & $\mathrm{Cl}$ & $44.7 \pm 10.5$ & $0.66 \pm 0.04$ & $62.9 \pm 2.7$ & $1.03 \pm 0.01$ \\
\hline$(+)-8$ & $\beta-\mathrm{CH}_{2} \mathrm{OAC}$ & $\mathrm{Cl}$ & $928 \pm 43$ & $0.89 \pm 0.04$ & $2023 \pm 82$ & $1.07 \pm 0.01$ \\
\hline$(-)-9$ & $\beta$-n-Pr & $\mathrm{Cl}$ & $3.0 \pm 0.5$ & $0.64 \pm 0.09$ & $8.3 \pm 0.6$ & $1.04 \pm 0.03$ \\
\hline$(-)-10$ & $\beta-\mathrm{CO}_{2} \mathrm{Me}$ & $\mathrm{H}$ & $769 \pm 19$ & $1.02 \pm 0.03$ & & \\
\hline$(+)-\mathbf{1 1}$ & $\alpha-\mathrm{CO}_{2} \mathrm{Me}$ & $\mathrm{Cl}$ & $57.3 \pm 8.1$ & $0.78 \pm 0.02$ & $34.6 \pm 3.2$ & $0.97 \pm 0.03$ \\
\hline$(-)-12$ & $\alpha-\mathrm{CO}_{2} \mathrm{Me}$ & $\mathrm{Cl}$ & $653 \pm 38$ & $0.96 \pm 0.01$ & $195 \pm 8$ & $1.08 \pm 0.03$ \\
\hline$(+)-13$ & $\alpha-\mathrm{CH}_{2} \mathrm{OH}$ & $\mathrm{Cl}$ & $240 \pm 18$ & $0.85 \pm 0.01$ & $683 \pm 47$ & $1.09 \pm 0.07$ \\
\hline$(+)-14$ & $\alpha-\mathrm{CH}_{2} \mathrm{OAC}$ & $\mathrm{Cl}$ & $461 \pm 11$ & $0.76 \pm 0.04$ & & \\
\hline$(+)-15$ & $\alpha-n-P r$ & $\mathrm{Cl}$ & $17.2 \pm 0.5$ & $0.85 \pm 0.01$ & $23.2 \pm 2.2$ & $1.03 \pm 0.01$ \\
\hline
\end{tabular}

mice. Clarke's racemic version of our piperidine $\mathbf{1 0}$ was found to have no stimulant activity when tested at 256 $\mathrm{mg} / \mathrm{kg}$ po in mice. It was this very lack of locomotor activity which caught our attention and led us to question whether these molecules had any affinity for the DAT. Our present demonstration that these piperidine structures do, in fact, possess significant DAT activity, taken together with their reported lack of locomotor activity, provides a compelling argument for exploring such compounds further as potential cocaine antagonists. The lack of any observed locomotor activity is unlikely to be due to the inability of the piperidines to cross the blood-brain barrier, as arecoline itself has shown some efficacy when administered intravenously to Alzheimer's patients. ${ }^{11}$ Moreover, in preliminary animal studies, we have found some of these piperidines to cause seizures when administered at high concentrations. Extensive studies of locomotor activity, selfadministration, and drug discrimination are now underway with several of the optically pure piperidines, and this work will be reported in due course.

Furthermore, it is informative to take note of the fact that the synthesis and activity of two more "cocainelike" piperidine anal ogues $\mathbf{1 6}$ and $\mathbf{1 7}$ have recently been disclosed. These two compounds, whose structures are shown below, exhibited I $\mathrm{C}_{50}$ 's for displacement of WIN 
35428 binding of 11589 and 8064 nM, respectively. ${ }^{12}$ Accordingly, both compounds are less active than cocaine or 4'-iodococaine $\left(\mathrm{IC}_{50}\right.$ 's reported for cocaine and for 4'-iodococaine are 249 and $2522 \mathrm{nM}$, respectively). The conclusion was accordingly reached that although the interatomic distances between the nitrogen atom of the piperidine ring and the iodine atom in compounds $\mathbf{1 6}$ and $\mathbf{1 7}$ are the same as that found in 4'-iodococaine, the lack of conformational rigidity of the piperidines or the adoption of the other chair conformations may lead to poor binding affinity. Given the high affinity found for our WIN series piperidines, we can conclude that in fact neither the loss of structural rigidity due to the absence of the two carbon bridge found in the tropanes nor conformational flexibility are problematic to achieving high compound potency.
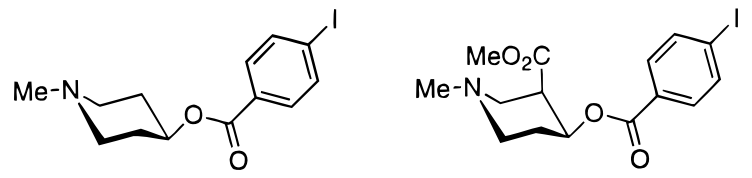

An interesting point of difference between our piperidines and the WIN series tropanes relates to the effect of epimerization of the ester substituent. In the case of WIN 35,065-2 which bears its ester and phenyl substituents in the $\beta$ orientation, conversion to WIN 35,140 which is its $\alpha$-ester counterpart results in a 59 -fold drop in binding affinity. ${ }^{13}$ Thus in this case, the effect of ester orientation has a substantial effect on binding. In general, the epimerization of the substituent at C-2 from $\beta$ to $\alpha$ in the tropane series has been reported to result in a lowering of activity by $30-200-$ fold. ${ }^{14}$ In sharp contrast to this result with the tropanes, the cis isomer (-)-3 is only about 2-fold more potent than the trans isomer $(+)$-11. This smaller spread in binding affinities for the piperidines may reflect the smaller size of these molecules relative to the tropanes, which allows both the cis and the trans isomers to adjust themselves to the binding site on the DAT. In the case of the tropanes, the presence of the two-carbon bridge may inhibit the C- $2 \alpha$-isomer from achieving the optimal fit, for enroute to this best fit the two carbon bridge may encounter a steric barrier resulting from its interaction with certain amino acids making up the transporter. A small difference in binding affinites for $\alpha$ - and $\beta$-isomers of the piperidine series is also observed with the n-propyl derivatives (-)-9 and (+)-15. In this case, the difference is about 5-fold.

As a further point of comparison, we draw attention to the effect that the presence or absence of a p-chloro substituent has on the binding of these piperidines. In the WIN series, it is now well appreciated through the work of Carroll that the introduction of a p-chloro or $\mathrm{p}$-iodo substituent to the aryl ring of $3 \beta$-phenyltropane$2 \beta$-carboxylic acid methyl ester results in compounds of higher potency in comparison to the unsubstituted parent structure. ${ }^{15}$ The reported I $\mathrm{C}_{50}$ 's of the p-chloro and p-iodo compounds in WIN 35,428 binding are 1.17 and $1.26 \mathrm{nM}$, respectively. This compares to $23 \mathrm{nM}$ for the parent structure. Thus the halogen atom increases binding affinity by 20 -fold. In the piperidine family of structures, the ratio of the $I \mathrm{C}_{50}$ 's for the dechloro compound (-)-10 relative to (-)-3 is $\mathbf{3 0}$. This parallel effect of halogen substitution on the in vitro activity of the piperidines would offer evidence in support of their binding to a similar site.

In conclusion, the potent DAT activity found for the piperidines reported herein, taken together with an earlier report of their lack of locomotor activity, suggests a further novel direction to pursue in the search for a cocaine abuse medication. The present work thus broadens the scope of structures that may be consi dered as lead structures in this search. Detailed biological studies in vivo employing several members of this family of piperidines will be reported in due course.

\section{Experimental Section}

General Methods. Starting materials were obtained from Aldrich Chemicals or from other commercial suppliers. Diethyl ether and cyclohexane were distilled from phosphorus pentoxide; THF was freshly distilled under nitrogen from sodium benzophenone.

IR spectra were recorded on an ATI Mattson Genesis spectrometer. ${ }^{1 \mathrm{H}}$ and ${ }^{13} \mathrm{C}$ NMR spectra were obtained with a Varian U nity I nova instrument at 300 and $75.46 \mathrm{MHz}$, respectively. ${ }^{1} \mathrm{H}$ chemical shifts $(\delta)$ are reported in ppm downfield from internal TMS. ${ }^{13} \mathrm{C}$ chemical shifts are referred to $\mathrm{CDCl}_{3}$ (central peak, $\delta=77.0 \mathrm{ppm}$ ), benzene-d $\mathrm{d}_{6}$ (central peak, $\delta=$ $128.0 \mathrm{ppm}$ ), or DMSO-d 6 (central peak, $\delta=39.7 \mathrm{ppm}$ ). NMR assignments were made with the help of COSY, DEPT, and HETCOR experiments.

Melting points were determined in Pyrex capillaries with a Thomas-Hoover Unimelt apparatus and are uncorrected. Mass spectra were measured in the EI mode at an ionization potential of $70 \mathrm{eV}$. TLC was performed on Merck silica gel $60 \mathrm{~F}_{254}$ glass plates; column chromatography was performed using Merck silica gel (60-200 mesh). The following abbreviations are used: DMSO = dimethyl sulfoxide; ether = diethyl ether; THF = tetrahydrofuran; $\mathrm{DCM}=$ dichloromethane.

rac-Methyl 4-(4-Chlorophenyl)-1-methylpiperidine-3carboxylate $(\mathbf{1}, 2)$. To a solution of 4-chlorophenylmagnesium bromide (166 mL, $1.0 \mathrm{M}$ in ether) in ether $(700 \mathrm{~mL})$ was added dropwise at $-10^{\circ} \mathrm{C}$ a solution of arecoline free base $(12.9 \mathrm{~g}$, $83 \mathrm{mmol}$, obtained from the hydrobromide by treatment with sodium bicarbonate and extraction into methylene chloride) in ether $(300 \mathrm{~mL})$. The mixture was stirred at $-10^{\circ} \mathrm{C}$ for 30 min, poured onto crushed ice, and treated slowly with $10 \%$ $\mathrm{HCl}(200 \mathrm{~mL})$. The aqueous layer was separated, washed with ether $(200 \mathrm{~mL})$, and then treated while cooling in an ice bath with a saturated solution of sodium bicarbonate $(100 \mathrm{~mL})$. The mixture was extracted with ether $(2 \times 200 \mathrm{~mL})$, and the combined organic phases were washed with brine $(200 \mathrm{~mL})$, dried, and concentrated under reduced pressure. The crude mixture was crystallized from EtOAc/hexane to afford the isomer $1(5.0 \mathrm{~g}, 22 \%)$ as a white solid. Concentration of the mother liquor gave a mixture of the $\mathbf{1}$ and $\mathbf{2}$ that was separated by flash chromatography on silica gel using ether/Et ${ }_{3} \mathrm{~N}, 9 / 1$, as eluent. The hydrochloride salts of these compounds were prepared by dissolution of the free bases in a methanolic solution of $\mathrm{HCl}(\mathrm{g})$, concentration, and final trituration of the crude salts with ether.

Compound $\mathbf{l}(12.4 \mathrm{~g}, 56 \%): \mathrm{mp} 98-99{ }^{\circ} \mathrm{C} ;{ }^{1} \mathrm{H} N M R\left(\mathrm{CDCl}_{3}\right)$ $\delta$ 1.74-1.86 (m, $\left.\mathrm{H}_{5 \mathrm{eq}}\right), 2.07$ (dt, $\mathrm{H}_{6 \mathrm{ax}} \mathrm{J}=3.0$ and $11.4 \mathrm{~Hz}$ ), $2.28(\mathrm{~s}, 3 \mathrm{H}), 2.35$ (dd, $\mathrm{H}_{2^{\prime}}, \mathrm{J}=3.6$ and $\left.11.7 \mathrm{~Hz}\right), 2.66\left(\mathrm{dq}, \mathrm{H}_{5 \mathrm{ax}}\right.$, $\mathrm{J}=3.9$ and $12.0 \mathrm{~Hz}$ ), $2.78\left(\mathrm{dt}, \mathrm{H}_{4}, \mathrm{~J}=3.6\right.$ and $\left.12.0 \mathrm{~Hz}\right), 2.9-$ $3.06\left(\mathrm{~m}, \mathrm{H}_{3}\right.$ and $\left.\mathrm{H}_{6 e \mathrm{eq}}\right), 3.18\left(\mathrm{bd}, \mathrm{H}_{2^{\prime \prime}} \mathrm{J} \mathrm{J}=12.0 \mathrm{~Hz}\right), 3.52(\mathrm{~s}, 3 \mathrm{H})$, $6.2-6.35(\mathrm{~m}, 4 \mathrm{H}) ;{ }^{13} \mathrm{C}$ NMR $\left(\mathrm{CDCl}_{3}\right) \delta 26.42\left(\mathrm{C}_{5}\right), 41.27\left(\mathrm{C}_{4}\right)$, $46.06\left(\mathrm{C}_{3}\right), 46.53\left(\mathrm{C}_{7}\right), 51.25\left(\mathrm{C}_{9}\right), 55.88\left(\mathrm{C}_{6}\right), 58.36\left(\mathrm{C}_{2}\right), 128.08$ $\left(C_{11}, C_{15}\right), 128.95\left(C_{12}, C_{14}\right), 131.79\left(C_{13}\right), 141.54\left(C_{10}\right), 172.47$

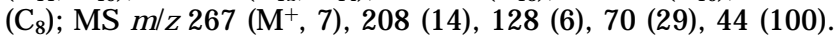

1. $\mathrm{HCl}$ : ${ }^{1 \mathrm{H}} \mathrm{NMR}$ (methanol- $\left.\mathrm{d}_{4}\right) \delta 2.05(\mathrm{bd}, 1 \mathrm{H}, \mathrm{J}=4.0 \mathrm{~Hz}$ ), $2.53(\mathrm{bq}, 1 \mathrm{H}, \mathrm{J}=10.8 \mathrm{~Hz}), 2.94(\mathrm{~s}, 3 \mathrm{H}), 3.14-3.5(\mathrm{~m}, 4 \mathrm{H}), 3.45$ $(\mathrm{s}, 3 \mathrm{H}), 3.6-3.7(\mathrm{~m}, 1 \mathrm{H}), 3.78(\mathrm{~d}, 1 \mathrm{H}, \mathrm{J}=12.9 \mathrm{~Hz}), 7.22(\mathrm{~d}$, 
$2 \mathrm{H}, \mathrm{J}=8.4 \mathrm{~Hz}), 7.35(\mathrm{~d}, 2 \mathrm{H}, \mathrm{J}=8.4 \mathrm{~Hz})$. Anal. $\left(\mathrm{C}_{14} \mathrm{H}_{18^{-}}\right.$ $\left.\mathrm{ClNO}_{2} \cdot \mathrm{HCl}\right) \mathrm{C}, \mathrm{H}, \mathrm{N}$.

Compound 2 (2.0 g, 18\%): ${ }^{1} \mathrm{H}$ NMR (benzene- $\left.\mathrm{d}_{6}\right) \delta$ 1.4-1.5 $(\mathrm{m}, 1 \mathrm{H}), 1.62(\mathrm{dq}, 1 \mathrm{H}, \mathrm{J}=3.9$ and $12.6 \mathrm{~Hz}), 1.75(\mathrm{dt}, 1 \mathrm{H}, \mathrm{J}=$ 2.7 and $12.0 \mathrm{~Hz}), 2.06(\mathrm{~s}, 3 \mathrm{H}), 2.0-2.15(\mathrm{~m}, 1 \mathrm{H}), 2.54-2.63$ $(\mathrm{m}, 1 \mathrm{H}), 2.68(\mathrm{dt}, 1 \mathrm{H}, \mathrm{J}=4.2$ and $11.7 \mathrm{~Hz}), 2.86-3.0(\mathrm{~m}, 2 \mathrm{H})$, $3.08(\mathrm{~s}, 3 \mathrm{H}), 6.87(\mathrm{~d}, 2 \mathrm{H}, \mathrm{J}=8.7 \mathrm{~Hz}), 7.07(\mathrm{~d}, 2 \mathrm{H}, \mathrm{J}=8.7 \mathrm{~Hz})$; ${ }^{13} \mathrm{C} \mathrm{NMR}\left(\mathrm{CDCl}_{3}\right) \delta 33.1,44.0,46.1,49.1,51.5,55.7,58.1,128.6$, 128.7, 132.3, 141.9, 173.4; MS m/z $267\left(\mathrm{M}^{+}, 17\right), 208$ (30), 128 (16), 114 (16), 43 (100).

2. $\mathrm{HCl}$ : ${ }^{1} \mathrm{H}$ NMR (methanol- $\left.\mathrm{d}_{4}\right) \delta 2.04-2.16(\mathrm{~m}, 2 \mathrm{H}), 2.97$ $(\mathrm{s}, 3 \mathrm{H}), 3.0-3.3(\mathrm{~m}, 4 \mathrm{H}), 3.47(\mathrm{~s}, 3 \mathrm{H}), 3.56-3.66(\mathrm{~m}, 1 \mathrm{H}), 3.7-$ $3.8(\mathrm{~m}, 1 \mathrm{H}), 7.25(\mathrm{~d}, 2 \mathrm{H}, \mathrm{J}=8.4 \mathrm{~Hz}), 7.34(\mathrm{~d}, 2 \mathrm{H}$, J $=8.4 \mathrm{~Hz})$. Anal. $\left(\mathrm{C}_{14} \mathrm{H}_{18} \mathrm{ClNO}_{2} \cdot \mathrm{HCl}\right) \mathrm{C}, \mathrm{H}, \mathrm{N}$.

(-)-Methyl 4/-(4-Chlorophenyl)-1-methylpiperidine3/ -carboxylate (3). To a solution of $\mathbf{1}(6.4 \mathrm{~g}, 24 \mathrm{mmol})$ in $\mathrm{MeOH}(200 \mathrm{~mL})$ was added a solution of dibenzoyl-L-tartaric acid $(8.9 \mathrm{~g}, 24 \mathrm{mmol})$ in $\mathrm{MeOH}(100 \mathrm{~mL})$. The resulting mixture was stirred at room temperature for $5 \mathrm{~h}$ and then filtered, and the white precipitate was washed with $\mathrm{MeOH} \mathrm{(20}$ $\mathrm{mL}$ ). This tartrate salt was treated with a saturated solution of $\mathrm{NaHCO}_{3}(150 \mathrm{~mL})$ and the mixture extracted with $\mathrm{CHCl}_{3}$ $(3 \times 100 \mathrm{~mL})$. The combined organic phases were washed with brine (150 mL), dried, and concentrated under reduced pressure to afford the title compound $(2.0 \mathrm{~g})$ as a white solid: $\mathrm{mp}$ $98-99^{\circ} \mathrm{C} ;[\alpha]^{25} \mathrm{D}-56^{\circ}$ (c $\left.1.0, \mathrm{EtOH}\right)$.

The hydrochloride salt was prepared by dissolution of the free base in a methanolic solution of $\mathrm{HCl}(\mathrm{g})$, concentration, and final trituration of the crude salt with ether: $[\alpha]^{25}-130^{\circ}$ (c 1.0, EtOH). Anal. $\left(\mathrm{C}_{14} \mathrm{H}_{18} \mathrm{ClNO}_{2} \cdot \mathrm{HCl} \cdot \mathrm{H}_{2} \mathrm{O}\right) \mathrm{C}, \mathrm{H}, \mathrm{N}$.

(+)-Methyl 4/-(4-Chlorophenyl)-1-methylpiperidine$3 \beta$-carboxylate (4). To the mixture of enantiomers derived from the mother liquor of previous separation $(4.2 \mathrm{~g}, 15.7$ $\mathrm{mmol})$ in $\mathrm{MeOH}(150 \mathrm{~mL})$ was added a solution of dibenzoylD-tartaric acid $(5.8 \mathrm{~g}, 15.7 \mathrm{mmol})$ in $\mathrm{MeOH}(50 \mathrm{~mL})$. The resulting mixture was stirred at room temperature for $5 \mathrm{~h}$ and then filtered, and the white precipitate was washed with $\mathrm{MeOH}(10 \mathrm{~mL})$. This tartrate salt was treated with a saturated solution of $\mathrm{NaHCO}_{3}(100 \mathrm{~mL})$ and the mixture extracted with $\mathrm{CHCl}_{3}(3 \times 70 \mathrm{~mL})$. The combined organic phases were washed with brine $(150 \mathrm{~mL})$, dried, and concentrated under reduced pressure to afford the title compound $(2.2 \mathrm{~g})$ as a white solid: $\mathrm{mp} 98-99^{\circ} \mathrm{C} ;[\alpha]^{25} \mathrm{D}+56^{\circ}$ (c 1.0, EtOH).

Preparation of the hydrochloride salt was made by dissolution of the free base in a methanolic solution of $\mathrm{HCl}(\mathrm{g})$, concentration, and final trituration of the crude salts with ether: $[\alpha]^{25}{ }_{D}+126^{\circ}$ (c 1.0, EtOH). Anal. $\left(\mathrm{C}_{14} \mathrm{H}_{18} \mathrm{CINO}_{2} \cdot \mathrm{HCl}\right)$ $\mathrm{C}, \mathrm{H}, \mathrm{N}$.

(-)-Methyl 4/-(4-Chlorophenyl)-1-methylpiperidine$3 \alpha$-carboxylate (12). To a sol ution of $4(0.4 \mathrm{~g}, 1.49 \mathrm{mmol})$ in $\mathrm{MeOH}$ ( $3 \mathrm{~mL}$ ) was added a $30 \%$ methanolic solution of sodium methoxide $(0.01 \mathrm{~mL})$. The resulting solution was stirred at reflux for $11 \mathrm{~h}$ and concentrated under reduced pressure. $\mathrm{CH}_{2-}$ $\mathrm{Cl}_{2}$ and a saturated solution of $\mathrm{NH}_{4} \mathrm{Cl}$ were added. The organic layer was washed with brine, dried over sodium sulfate, and concentrated under reduced pressure to afford $\mathbf{4}$ and $\mathbf{1 2}$ in a 1:5.6 ratio (determined by GC-MS analysis). Purification of the crude product by silica gel flash chromatography using ether/Et $t_{3} \mathrm{~N}, 9.8 / 0.2$, as eluent afforded the title compound $(0.35$ $\mathrm{g}, 85 \%)$ as a colorless oil: $[\alpha]^{25} \mathrm{D}-50^{\circ}$ (c 1.0, EtOH). Anal. $\left(\mathrm{C}_{14} \mathrm{H}_{18} \mathrm{ClNO}_{2}\right) \mathrm{C}, \mathrm{H}, \mathrm{N}$.

(+)-Methyl 4/-(4-Chlorophenyl)-1-methylpiperidine3 $\alpha$-carboxylate (11). To a solution of $\mathbf{3}(0.5 \mathrm{~g}, 1.87 \mathrm{mmol})$ in $\mathrm{MeOH}(6 \mathrm{~mL})$ was added a $30 \%$ methanolic solution of sodium methoxide $(0.04 \mathrm{~mL})$. The resulting solution was stirred at reflux for $24 \mathrm{~h}$ and concentrated under reduced pressure. $\mathrm{CH}_{2^{-}}$ $\mathrm{Cl}_{2}$ and brine were added, and the organic layer was washed with brine. Concentration of the combined organic phase afforded $\mathbf{3}$ and $\mathbf{1 1}$ in a 1:32 ratio (determined by GC-MS analysis). Purification of the crude product by silica gel flash chromatography using ether/E $t_{3} \mathrm{~N}, 9.8 / 0.2$, as el uent afforded the title compound $(0.43 \mathrm{~g}, 86 \%)$ as a colorless oil: $[\alpha]^{25} \mathrm{D}+46^{\circ}$ (c 1.0, EtOH).
The hydrochloride salt was prepared by dissolution of the free base in a methanolic solution of $\mathrm{HCl}(\mathrm{g})$, resulting in a direct crystallization of the desired salt: $[\alpha]^{25} \mathrm{D}+55^{\circ}$ (c 0.5 , EtOH $) ; m p>230{ }^{\circ} \mathrm{C}$. Anal. $\left(\mathrm{C}_{14} \mathrm{H}_{18} \mathrm{CINO}_{2} \cdot \mathrm{HCl}\right) \mathrm{C}, \mathrm{H}, \mathrm{N}$.

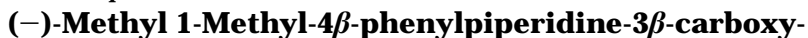
late (10). A mixture of $3(0.7 \mathrm{~g}, 2.61 \mathrm{mmol})$ and $10 \% \mathrm{Pd} / \mathrm{C}$ $(0.28 \mathrm{~g})$ in $\mathrm{MeOH}(20 \mathrm{~mL})$ was hydrogenated under 1 atm of $\mathrm{H}_{2}$ for $3 \mathrm{~h}$. The resulting mixture was filtered over Celite and evaporated to dryness. The resulting pale yellow oil was purified by flash chromatography on silica gel using ether/ $\mathrm{Et}_{3} \mathrm{~N}, 9.5 / 0.5$, as eluent to afford the title compound $(0.6 \mathrm{~g}$, $98 \%)$ as a colorless oil: $[\alpha]^{25} \mathrm{D}-54^{\circ}$ (c 1, EtOH); ${ }^{1 \mathrm{H}} \mathrm{NMR}$ $\left(\mathrm{CDCl}_{3}\right) \delta 1.76-1.9\left(\mathrm{~m}, \mathrm{H}_{5 \mathrm{eq}}\right), 2.09$ (dt, $\mathrm{H}_{6 \mathrm{ax}} \mathrm{J}=2.7$ and 11.1 $\mathrm{Hz}), 2.29\left(\mathrm{~s}, 3 \mathrm{H}\right.$ ), $2.37\left(\mathrm{dd}, \mathrm{H}_{2^{\prime}}, \mathrm{J}=3.6\right.$ and $\left.11.7 \mathrm{~Hz}\right), 2.70(\mathrm{dq}$, $\mathrm{H}_{5 a x}, \mathrm{~J}=3.9$ and $\left.12.3 \mathrm{~Hz}\right), 2.85\left(\mathrm{dt}, \mathrm{H}_{4}, \mathrm{~J}=3.9\right.$ and $\left.11.7 \mathrm{~Hz}\right)$, 2.92-3.06 ( $\mathrm{m}, \mathrm{H}_{3}$ and $\left.\mathrm{H}_{6 \mathrm{eq}}\right), 3.18\left(\mathrm{br} \mathrm{d}, \mathrm{H}_{2^{\prime \prime}} \mathrm{J}=12.0 \mathrm{~Hz}\right), 3.50$ (s, 3H), 7.1-7.4 (m, 5H); ${ }^{13} \mathrm{C} \mathrm{NMR}\left(\mathrm{CDCl}_{3}\right) \delta 26.6,41.8,46.2$, 46.6, 51.2, 55.9, 58.3, 126.1, 127.6, 128.0, 143.0, 172.7; MS m/z $233\left(\mathrm{M}^{+}, 13\right), 232(6), 174$ (17), 70 (26), 44 (100).

Preparation of the hydrochloride salt was made by dissolution of the free base in a methanolic solution of $\mathrm{HCl}(\mathrm{g})$, concentration, and final trituration of the crude salts with ether: $[\alpha]^{25} \mathrm{D}-130^{\circ}$ (c 1.0, EtOH); mp $168-169{ }^{\circ} \mathrm{C} ;{ }^{1} \mathrm{H}$ NMR (methanol- $\left.\mathrm{d}_{4}\right) \delta 2.0-2.1(\mathrm{~m}, 1 \mathrm{H}), 2.5-2.7(\mathrm{~m}, 1 \mathrm{H}), 2.95(\mathrm{~s}, 3 \mathrm{H})$, $3.1-3.5(\mathrm{~m}, 4 \mathrm{H}), 3.42(\mathrm{~s}, 3 \mathrm{H}), 3.6-3.7(\mathrm{~m}, 2 \mathrm{H}), 3.7-3.85(\mathrm{~m}$, $1 \mathrm{H}), 7.2-7.4(\mathrm{~m}, 5 \mathrm{H})$. Anal. $\left(\mathrm{C}_{14} \mathrm{H}_{19} \mathrm{NO}_{2} \cdot \mathrm{HCl}\right) \mathrm{C}, \mathrm{H}, \mathrm{N}$.

(-)-4/-(4-Chlorophenyl)-3 $\beta$-(hydroxymethyl)-1-methylpiperidine (5). To a solution of $\mathbf{3}(1.0 \mathrm{~g}, 3.7 \mathrm{mmol})$ in THF (30 mL) was added portionwise $\mathrm{LiAlH}_{4}(0.3 \mathrm{~g}, 7.5 \mathrm{mmol})$. The resulting mixture was stirred at room temperature for $2 \mathrm{~h}$, and then a saturated solution of Rochelle salt $(30 \mathrm{~mL})$ was added followed by extraction with EtOAc $(100 \mathrm{~mL})$. The organic phase was washed with brine $(100 \mathrm{~mL})$, dried, and concentrated under reduced pressure to afford the title compound $(0.9 \mathrm{~g}, 98 \%)$ as a colorless oil: $[\alpha]^{25} \mathrm{D}-70^{\circ}(\mathrm{c} 1.0, \mathrm{EtOH})$; ${ }^{1} \mathrm{H}$ NMR $\left(\mathrm{CDCl}_{3}\right) \delta$ 1.64-1.84 $\left(\mathrm{m}, \mathrm{H}_{3}\right.$ and $\left.\mathrm{H}_{5 e q}\right), 2.11\left(\mathrm{dt}, \mathrm{H}_{6 a x}\right.$, $\mathrm{J}=3.3$ and $11.7 \mathrm{~Hz}), 2.29(\mathrm{~s}, 3 \mathrm{H}), 2.45\left(\mathrm{dt}, \mathrm{H}_{\mathrm{I}^{\prime}} \mathrm{J}=2.7\right.$ and $11.4 \mathrm{~Hz}$ ), 2.55 (dq, $\mathrm{H}_{5 a x} \mathrm{~J}=4.2$ and $\left.12.6 \mathrm{~Hz}\right), 2.84\left(\mathrm{dt}, \mathrm{H}_{4}, \mathrm{~J}\right.$ $=4.5$ and $13.5 \mathrm{~Hz}), 3.0-3.1\left(\mathrm{~m}, \mathrm{H}_{6 e q}\right), 3.14\left(\mathrm{br} \mathrm{d}, \mathrm{H}_{2 \prime \prime}, \mathrm{J}=11.4\right.$ $\mathrm{Hz}), 3.54\left(\mathrm{dt}, \mathrm{H}_{8}, \mathrm{~J}=2.4\right.$ and $\left.10.8 \mathrm{~Hz}\right), 3.70\left(\mathrm{dd}, \mathrm{H}_{8}, \mathrm{~J}=3.3\right.$ and $11.1 \mathrm{~Hz}), 7.24(\mathrm{~d}, 2 \mathrm{H}, \mathrm{J}=8.7 \mathrm{~Hz}), 7.29(\mathrm{~d}, 2 \mathrm{H}, \mathrm{J}=8.7$ $\mathrm{Hz}) ;{ }^{13} \mathrm{C} N M R\left(\mathrm{CDCl}_{3}\right) \delta 27.9\left(\mathrm{C}_{4}\right), 40.2\left(\mathrm{C}_{2}\right), 43.5\left(\mathrm{C}_{3}\right), 46.3$ $\left(C_{6}\right), 56.2\left(C_{1}\right), 61.4\left(C_{5}\right), 64.5\left(C_{8}\right), 128.4\left(C_{11}, C_{15}\right), 129.2\left(C_{12}\right.$, $\left.\mathrm{C}_{14}\right), 131.9\left(\mathrm{C}_{13}\right), 142.1\left(\mathrm{C}_{10}\right)$; MS m/z $239\left(\mathrm{M}^{+}, 6\right), 208(6), 100$ (16), 44 (100). Anal. $\left(\mathrm{C}_{13} \mathrm{H}_{18} \mathrm{CINO}\right) \mathrm{C}, \mathrm{H}, \mathrm{N}$.

(+)-4/-(4-Chlorophenyl)-3/3-(hydroxymethyl)-1-methylpiperidine (6) was prepared similarly to 5. From 4 there was obtained $6(82 \%)$ as a col orless oil, $[\alpha]^{25} \mathrm{D}+67^{\circ}(\mathrm{c} 1, \mathrm{EtOH})$. Anal. $\left(\mathrm{C}_{13} \mathrm{H}_{18} \mathrm{CINO}\right) \mathrm{C}, \mathrm{H}, \mathrm{N}$.

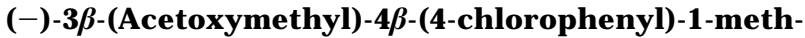
ylpiperidine (7). To a solution of $5(90 \mathrm{mg}, 0.38 \mathrm{mmol})$ in pyridine $(2 \mathrm{~mL})$ was added acetic anhydride $(0.5 \mathrm{~mL})$. The resulting solution was stirred at room temperature for $15 \mathrm{~h}$, then concentrated under reduced pressure, diluted with EtOAc $(30 \mathrm{~mL})$, and washed with a saturated solution of $\mathrm{NH}_{4} \mathrm{Cl}(2 \times$ $20 \mathrm{~mL}$ ). The organic solution was dried and concentrated under reduced pressure to afford the title compound $(0.10 \mathrm{~g}$, 95\%) as a white solid: $\mathrm{mp} 76^{\circ} \mathrm{C}$; $[\alpha]^{25} \mathrm{D}-109^{\circ}$ (c 0.75 ; EtOH); $\mathrm{R}_{\mathrm{f}} 0.6$ (ether/Et $\left.\mathrm{t}_{3} \mathrm{~N}, 9.5 / 0.5\right) ;{ }^{1} \mathrm{H}$ NMR (benzene- $\mathrm{d}_{6}$ ) $\delta 1.21$ (br d, $1 \mathrm{H}, \mathrm{J}=11.4 \mathrm{~Hz}), 1.52(\mathrm{~s}, 3 \mathrm{H}), 1.72(\mathrm{dq}, 1 \mathrm{H}, \mathrm{J}=3.0$ and 12.3 $\mathrm{Hz}), 1.6-1.7(\mathrm{~m}, 1 \mathrm{H}), 1.86(\mathrm{dd}, 1 \mathrm{H}, \mathrm{J}=2.7$ and $11.4 \mathrm{~Hz}), 2.0$ $2.1(\mathrm{~m}, 1 \mathrm{H}), 2.09(\mathrm{~s}, 3 \mathrm{H}), 2.40(\mathrm{dt}, 1 \mathrm{H}, \mathrm{J}=3.9$ and $11.4 \mathrm{~Hz})$, $2.67(\mathrm{br} \mathrm{d}, 1 \mathrm{H}, \mathrm{J}=8.1 \mathrm{~Hz}), 2.91(\mathrm{~d}, 1 \mathrm{H}, \mathrm{J}=11.4 \mathrm{~Hz}), 3.90$ (dd, $1 \mathrm{H}, \mathrm{J}=4.5$ and $10.8 \mathrm{~Hz}), 4.47(\mathrm{dd}, 1 \mathrm{H}, \mathrm{J}=9.6$ and 10.5 $\mathrm{Hz}), 6.68(\mathrm{~d}, 2 \mathrm{H}, \mathrm{J}=8.4 \mathrm{~Hz}), 7.09(\mathrm{~d}, 2 \mathrm{H}, \mathrm{J}=8.4 \mathrm{~Hz}) ;{ }^{13} \mathrm{C}$ NMR $\left(\mathrm{CDCl}_{3}\right) \delta 20.8,25.6,39.6,41.9,46.5,56.2,57.8,62.5$, $128.4,128.5,132.0,141.5,170.9 ; \mathrm{MS} \mathrm{m} / \mathrm{z} 281\left(\mathrm{M}^{+}, 6\right), 238(6)$, 208 (15), 142 (7), 44 (100). Anal. $\left(\mathrm{C}_{15} \mathrm{H}_{20} \mathrm{CINO}_{2}\right) \mathrm{C}, \mathrm{H}, \mathrm{N}$.

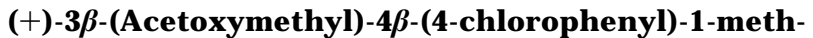
ylpiperidine (8) was prepared similarly to 7. From 6 there was obtained $5(93 \%)$ as a white solid: $[\alpha]^{25} \mathrm{D}+107^{\circ}$ (c 0.35 , EtOH); MS m/z $281\left(\mathrm{M}^{+}, 6\right)$. Anal. $\left(\mathrm{C}_{15} \mathrm{H}_{20} \mathrm{CINO} \mathrm{NO}_{2}\right) \mathrm{C}, \mathrm{H}, \mathrm{N}$.

(-) 4/-(4-chlorophenyl)-1-methyl-3/3-n-propylpiperidine (9). Oxalyl chloride $(0.19 \mathrm{~mL})$ was dissolved in anhy- 
drous $\mathrm{CH}_{2} \mathrm{Cl}_{2}(15 \mathrm{~mL})$, and the solution was cooled to $-78{ }^{\circ} \mathrm{C}$. Dimethyl sulfoxide $(0.32 \mathrm{~mL})$ was added, after $5 \mathrm{~min}$ the al cohol $5(0.5 \mathrm{~g}, 2.08 \mathrm{mmol})$ was added in $\mathrm{CH}_{2} \mathrm{Cl}_{2}(5 \mathrm{~mL})$, and stirring was continued for $30 \mathrm{~min}$. The reaction mixture was quenched by adding $\mathrm{Et}_{3} \mathrm{~N}(2.84 \mathrm{~mL})$, and the resulting solution was warmed to room temperature, diluted with $\mathrm{CH}_{2} \mathrm{Cl}_{2}$ (30 $\mathrm{mL})$, washed with $\mathrm{NH}_{4} \mathrm{Cl}(2 \times 30 \mathrm{~mL})$, dried, and concentrated under reduced pressure to provide the intermediate al dehyde $(0.45 \mathrm{~g}, 91 \%)$ as a colorless oil used in the next step without further purification: ${ }^{1} \mathrm{H} \mathrm{NMR}\left(\mathrm{CDCl}_{3}\right) \delta 1.9-2.0(\mathrm{~m}, 1 \mathrm{H}), 2.10$ $(\mathrm{dt}, 1 \mathrm{H}, \mathrm{J}=2.4$ and $11.4 \mathrm{~Hz}), 2.29(\mathrm{~s}, 3 \mathrm{H}), 2.2-2.4(\mathrm{~m}, 2 \mathrm{H})$, 2.64-2.74 (m, 1H), $2.92(\mathrm{dt}, 1 \mathrm{H}, \mathrm{J}=3.9$ and $12.9 \mathrm{~Hz}), 3.0-$ $3.1(\mathrm{~m}, 1 \mathrm{H}), 3.28(\mathrm{br} \mathrm{d}, 1 \mathrm{H}, \mathrm{J}=11.4 \mathrm{~Hz}), 7.2(\mathrm{~d}, 2 \mathrm{H}, \mathrm{J}=8.4$ $\mathrm{Hz}), 7.29(\mathrm{~d}, 2 \mathrm{H}, \mathrm{J}=8.4 \mathrm{~Hz}), 8.7(\mathrm{~s}, 1 \mathrm{H}) ;{ }^{13} \mathrm{C} \mathrm{NMR}\left(\mathrm{CDCl}_{3}\right) \delta$ 27.2, 40.9, 46.5, 51.9, 55.9, 57.0, 128.6, 128.7, 132.3, 140.6, 203.9.

A solution of $\mathrm{n}$-BuLi $(2.28 \mathrm{~mL}, 1 \mathrm{M}$ in hexane, $5.7 \mathrm{mmol})$ was dissolved in THF $(10 \mathrm{~mL})$ and cooled to $0{ }^{\circ} \mathrm{C}$. Ethyltriphenylphosphonium bromide $(2.1 \mathrm{~g}, 5.7 \mathrm{mmol})$ was added slowly under nitrogen. The resulting yellow-orange solution was stirred at $0{ }^{\circ} \mathrm{C}$ for $30 \mathrm{~min}$, and then the cool ing bath was removed. The crude aldehyde $(0.45 \mathrm{~g}, 1.9 \mathrm{mmol})$ was added in THF (2 mL), and the reaction mixture was stirred for $15 \mathrm{~h}$ at room temperature, diluted with EtOAc $(20 \mathrm{~mL})$, and washed with a saturated solution of $\mathrm{NH}_{4} \mathrm{Cl}(2 \times 30 \mathrm{~mL})$. The organic phase was extracted with $10 \% \mathrm{HCl}(3 \times 10 \mathrm{~mL})$. The combined aqueous phases were washed with EtOAc $(30 \mathrm{~mL})$, neutralized with a saturated solution of $\mathrm{NaHCO}_{3}$, and extracted with $\mathrm{CH}_{2} \mathrm{Cl}_{2}(2 \times 30 \mathrm{~mL})$. The combined organic phases were dried and concentrated under reduced pressure, and the residue was purified by flash chromatography on silica gel using ether/ $E t_{3} N, 9.5 / 0.5$, as eluent to afford the olefin intermediate as a mixture of the cis and trans isomers $(0.3 \mathrm{~g}$, 63\%): MS m/z $248\left(M^{+}, 6\right), 57$ (100).

To a solution of the intermediate ol efins $(0.2 \mathrm{~g}, 0.80 \mathrm{mmol})$ in cyclohexane $(20 \mathrm{~mL})$ was added $5 \% \mathrm{Pt} / \mathrm{C}(0.2 \mathrm{~g})$. The mixture was stirred at room temperature for 30 min under 40 psi of $\mathrm{H}_{2}$. The resulting solution was filtered over Celite and evaporated to dryness. The resulting colorless oil was purified by flash chromatography on silica gel using ether/Et ${ }_{3} \mathrm{~N}, 9.5 /$ 0.5 , as eluent to afford the title compound $9(0.19 \mathrm{~g}, 94 \%)$ as a colorless oil: $[\alpha]^{25} \mathrm{D}-84^{\circ}$ (c $\left.0.5, \mathrm{EtOH}\right) ;{ }^{1} \mathrm{H}$ NMR (benzene$\left.\mathrm{d}_{6}\right) \delta 0.71(\mathrm{t}, 3 \mathrm{H}, \mathrm{J}=6.9 \mathrm{~Hz}), 0.75-1.0(\mathrm{~m}, 2 \mathrm{H}), 1.2-1.4(\mathrm{~m}$, $2 \mathrm{H}), 1.52-1.65(\mathrm{~m}, 1 \mathrm{H}), 1.65-1.84(\mathrm{~m}, 2 \mathrm{H}), 1.84-2.0(\mathrm{~m}, 2 \mathrm{H})$, $2.14(\mathrm{~s}, 3 \mathrm{H}), 2.47(\mathrm{dt}, 1 \mathrm{H}, \mathrm{J}=3.6$ and $12.3 \mathrm{~Hz}), 2.7-2.84(\mathrm{~m}$, $1 \mathrm{H}), 6.77(\mathrm{~d}, 2 \mathrm{H}, \mathrm{J}=8.4 \mathrm{~Hz}), 7.15(\mathrm{~d}, 2 \mathrm{H}, \mathrm{J}=8.4 \mathrm{~Hz}) ;{ }^{13} \mathrm{C}$ NMR $\left(\mathrm{CDCl}_{3}\right) \delta 14.0,21.1,25.4,27.6,40.2,43.9,46.8,56.5$, 59.4, 128.1, 128.8, 131.4, 142.9; MS m/z $251\left(\mathrm{M}^{+}, 8\right), 208$ (8), 112 (24), 44 (100).

Preparation of the hydrochloride salt was made by dissolution of the free base in a methanolic solution of $\mathrm{HCl}(\mathrm{g})$, concentration, and final trituration of the crude salt with ether: $\mathrm{mp}>230{ }^{\circ} \mathrm{C} ;[\alpha]^{25} \mathrm{D}-73^{\circ}$ (c $\left.0.25, \mathrm{EtOH}\right) ;{ }^{1} \mathrm{H} N M R$ (methanol- $\left.\mathrm{d}_{4}\right) \delta 0.78(\mathrm{t}, 3 \mathrm{H}, \mathrm{J}=6.6 \mathrm{~Hz}), 0.9-1.1(\mathrm{~m}, 2 \mathrm{H})$, $1.28-1.5(\mathrm{~m}, 2 \mathrm{H}), 1.94-2.06(\mathrm{~m}, 1 \mathrm{H}), 2.14-2.38(\mathrm{~m}, 2 \mathrm{H})$, $2.92(\mathrm{~s}, 3 \mathrm{H}), 3.04-3.4(\mathrm{~m}, 3 \mathrm{H}), 3.54-3.7(\mathrm{~m}, 2 \mathrm{H}), 7.24(\mathrm{~d}, 2 \mathrm{H}$, $\mathrm{J}=7.8 \mathrm{~Hz}), 7.35(\mathrm{~d}, 2 \mathrm{H}$, J $=7.8 \mathrm{~Hz})$. Anal. $\left(\mathrm{C}_{15} \mathrm{H}_{22} \mathrm{CIN} \cdot \mathrm{HCl}\right)$ $\mathrm{C}, \mathrm{H}, \mathrm{N}$.

(+)-4/-(4-Chlorophenyl)-3 $\alpha$-(hydroxymethyl)-1-methylpiperidine (13) was prepared similarly to 5. From 11 there was obtained $13(84 \%)$ as a colorless oil: $[\alpha]^{25} \mathrm{D}+38^{\circ}$ (c 0.5 , EtOH); mp $148-150{ }^{\circ} \mathrm{C}$; ${ }^{1} \mathrm{H} \mathrm{NMR}\left(\mathrm{CDCl}_{3}\right) \delta 1.4$ (br s, OH), $1.7-2.1(\mathrm{~m}, 5 \mathrm{H}), 2.29(\mathrm{dd}, 1 \mathrm{H}, \mathrm{J}=5.4$ and $10.5 \mathrm{~Hz}), 2.36(\mathrm{~s}$, $3 \mathrm{H}), 2.95(\mathrm{~d}, 1 \mathrm{H}, \mathrm{J}=10.8 \mathrm{~Hz}), 3.15(\mathrm{~d}, 1 \mathrm{H}, \mathrm{J}=10.8 \mathrm{~Hz})$, $3.24(\mathrm{dd}, 1 \mathrm{H}, \mathrm{J}=6.6$ and $10.8 \mathrm{~Hz}), 3.41(\mathrm{dd}, 1 \mathrm{H}, \mathrm{J}=3.0$ and $10.8 \mathrm{~Hz}), 7.14(\mathrm{~d}, 2 \mathrm{H}, \mathrm{J}=8.4 \mathrm{~Hz}), 7.27(\mathrm{~d}, 2 \mathrm{H}, \mathrm{J}=8.4 \mathrm{~Hz})$. Anal. $\left(\mathrm{C}_{13} \mathrm{H}_{18} \mathrm{CINO}\right) \mathrm{C}, \mathrm{H}, \mathrm{N}$.

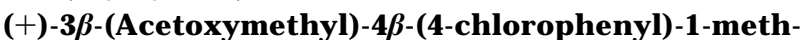
ylpiperidine (14) was prepared similarly to 7. From 13 there was obtained $14(80 \%)$ as a white solid: ${ }^{1} \mathrm{H}$ NMR $\left(\mathrm{CDCl}_{3}\right) \delta$ $1.7-1.9(\mathrm{~m}, 3 \mathrm{H}), 1.97(\mathrm{~s}, 3 \mathrm{H}), 1.95-2.1(\mathrm{~m}, 1 \mathrm{H}), 2.1-2.3(\mathrm{~m}$, $2 \mathrm{H}), 2.35(\mathrm{~s}, 3 \mathrm{H}), 2.95(\mathrm{~d}, 1 \mathrm{H}, \mathrm{J}=11.4 \mathrm{~Hz}), 3.07(\mathrm{~d}, 1 \mathrm{H}, \mathrm{J}$ $=9.6 \mathrm{~Hz}), 3.63(\mathrm{dd}, 1 \mathrm{H}, \mathrm{J}=7.5$ and $11.4 \mathrm{~Hz}), 3.82(\mathrm{dd}, 1 \mathrm{H}$, $\mathrm{J}=3.0$ and $11.1 \mathrm{~Hz}), 7.12(\mathrm{~d}, 2 \mathrm{H}, \mathrm{J}=8.4 \mathrm{~Hz}), 7.27(\mathrm{~d}, 2 \mathrm{H}$,
$J=8.4 \mathrm{~Hz}) ;{ }^{13} \mathrm{C} \mathrm{NMR}\left(\mathrm{CDCl}_{3}\right) \delta 20.7,34.4,41.0,44.2,46.4$ 56.0, 59.3, 65.2, 128.7, 128.8, 132.2, 142.1, 170.9. Anal. $\left(\mathrm{C}_{15} \mathrm{H}_{20} \mathrm{CINO}\right) \mathrm{C}, \mathrm{H}, \mathrm{N}$.

(+)-4/-(4-chlorophenyl)-1-methyl-3 $\alpha$-n-propylpiperidine (15) was prepared similarly to $\mathbf{9}$. From $\mathbf{1 3}$ there was obtained $15(70 \%)$ as a col orless oil: $[\alpha]^{25} \mathrm{D}+41^{\circ}(\mathrm{c} 1.0, \mathrm{EtOH})$; ${ }^{1} \mathrm{H} \mathrm{NMR}\left(\mathrm{CDCl}_{3}\right) \delta 0.73(\mathrm{t}, 3 \mathrm{H}$, J $=7.2 \mathrm{~Hz}), 0.8-1.0(\mathrm{~m}, 1 \mathrm{H})$, $1.0-1.2(\mathrm{~m}, 2 \mathrm{H}), 1.2-1.4(\mathrm{~m}, 1 \mathrm{H}), 1.65(\mathrm{t}, 1 \mathrm{H}, \mathrm{J}=10.8 \mathrm{~Hz})$, 1.7-1.9 (m, $3 \mathrm{H}), 1.9-2.15(\mathrm{~m}, 2 \mathrm{H}), 2.32(\mathrm{~s}, 3 \mathrm{H}), 2.93(\mathrm{~d}, 1 \mathrm{H}$, $\mathrm{J}=11.1 \mathrm{~Hz}), 3.05(\mathrm{~d}, 1 \mathrm{H}, \mathrm{J}=10.8 \mathrm{~Hz}), 7.10(\mathrm{~d}, 2 \mathrm{H}, \mathrm{J}=8.4$ $\mathrm{Hz}), 7.25(\mathrm{~d}, \mathrm{~J}=8.1 \mathrm{~Hz}) ;{ }^{13} \mathrm{C} \mathrm{NMR}\left(\mathrm{CDCl}_{3}\right) \delta 14.1,19.7,33.9$, 35.0, 40.8, 46.5, 48.2, 56.3, 61.6, 128.5, 129.0, 131.6, 143.8.

Preparation of the hydrochloride salt was made by dissolution of the free base in a methanolic solution of $\mathrm{HCl}(\mathrm{g})$, concentration, and final trituration of the crude salts with ether: $[\alpha]^{25} \mathrm{D}+34^{\circ}\left(\mathrm{c} 0.25\right.$, EtOH ); $\mathrm{mp} 216^{\circ} \mathrm{C}$ (EtOAC); ${ }^{1} \mathrm{H}$ NMR (methanol- $\left.\mathrm{d}_{4}\right) \delta 0.77(\mathrm{t}, 3 \mathrm{H}, \mathrm{J}=6.9 \mathrm{~Hz}), 1.0-1.4(\mathrm{~m}, 4 \mathrm{H})$, $1.9-2.2(\mathrm{~m}, 3 \mathrm{H}), 2.56(\mathrm{q}, 1 \mathrm{H}, \mathrm{J}=10.8 \mathrm{~Hz}), 2.86(\mathrm{t}, 1 \mathrm{H}, \mathrm{J}=$ $12.6 \mathrm{~Hz}), 2.93(\mathrm{~s}, 3 \mathrm{H}), 3.0-3.2(\mathrm{~m}, 1 \mathrm{H}), 3.5-3.7(\mathrm{~m}, 2 \mathrm{H})$, $7.23(\mathrm{~d}, 2 \mathrm{H}, \mathrm{J}=8.4 \mathrm{~Hz}), 7.35(\mathrm{~d}, 2 \mathrm{H}, \mathrm{J}=8.4 \mathrm{~Hz})$. Anal. $\left(\mathrm{C}_{15} \mathrm{H}_{22} \mathrm{ClN} \cdot \mathrm{HCl}\right) \mathrm{C}, \mathrm{H}, \mathrm{N}$.

Single-Crystal X-ray Analysis of the (-)-Dibenzoyltartrate of 3. A clear rectangular $0.06 \times 0.08 \times 0.52 \mathrm{~mm}$ crystal, $\mathrm{C}_{14} \mathrm{H}_{19} \mathrm{O}_{2} \mathrm{CIN}^{+} \mathrm{C}_{18} \mathrm{H}_{13} \mathrm{O}_{8}^{-}, \mathrm{FW}=626.04$, was selected for data collection. Data were collected on a computercontrolled Siemens CCD $1 \mathrm{~K}$ area detector system with a Siemens PLATFORM goniometer using a Rigaku rotating anode source and Gobel mirrors ( $\mathrm{Cu} K \alpha$ radiation, $\lambda=1.54178$ $\AA, T=295 \mathrm{~K})$. Data collection nominally covered a hemisphere in reciprocal space by combining six sets of exposures with different $2 \theta$ and $\phi$ angles: each exposure covered a range of $0.75^{\circ}$ in $\omega$. The crystal to detector distance was $5.09 \mathrm{~cm}$, and coverage of a unique set was $98 \%$ complete to $1.0 \AA$ resolution. The crystal decay was monitored by repeating 50 of the initial frames at the end of data collection and was found to be $2.7 \%$. A least-squares refinement ${ }^{16}$ using 176 centered reflections within $16.2<2 \theta<34.4^{\circ}$ gave the orthorhombic $P 2_{1} 2_{1} 2_{1}$ cell, $a=7.752(3) \AA, b=14.691(5) \AA, c=27.502(8) \AA$, with $V=$ $3132.2(17) \AA^{3}, Z=4$, and $d_{\text {calc }}=1.328 \mathrm{gm} / \mathrm{cm}^{3}$. A total of 8342 reflections were to $2 \theta_{\max }=100^{\circ}$, of which there were 2923 independent reflections. Corrections were applied for L orentz and polarization effects. An empirical absorption correction was applied using equivalent reflections (SADABS ${ }^{17}$ ), $\mu=$ $1.577 \mathrm{~mm}^{-1}$. Maximum and minimum transmission were 0.44 and 0.88 , respectively. The structure was solved by direct methods with the aid of the program SHELXTI ${ }^{18}$ and refined on $\mathrm{F}^{2}$ with full matrix least-squares. ${ }^{18}$ The 398 parameters refined include the coordinates and anisotropic thermal parameters for all non-hydrogen atoms. Hydrogens were included using a riding model. The final $R$ values for the 2244 observed reflections with $\mathrm{F}_{\mathrm{o}}>4 \sigma\left(\left|\mathrm{F}_{\mathrm{o}}\right|\right)$ were $\mathrm{R}=0.086$ and $\mathrm{wR}$ $\left(F^{2}\right)=0.208$. The goodness of fit parameter was 1.07 , and final difference Fourier excursions were 0.41 and -0.27 e $\AA^{-3}$. The absolute configuration determination was based on a method suggested by D. Rogers. ${ }^{19}$ The absolute structure parameter which should be near 0.0 for the correct choice of chirality and 1.0 for an incorrect choice was 0.04(6). The compound also contained a chiral anion, (-)-dibenzoyltartaric acid.

Acknowledgment. We are indebted to the National Institutes of Health, National I nstitute on Drug Abuse (DA11546), for their support of these studies.

\section{References}

(1) J ohanson, C.-E.; Fischman, M. W. The Pharmacology of Cocaine Related to its Abuse. Pharmacol. Rev. 1989, 41, 3-52. Clouet, D.; Asghar, K.; Brown, R. (Eds.) Mechanisms of Cocaine Abuse and Toxicity. NIDA Res. Monogr. 1988, 88.

(2) Kleber, H. D.; Gawin, F. H. Cocaine: Pharmacology, Effects, and Treatment of Abuse. NIDA Res. Monogr. Grabowski, J . (Ed.), 1984, 50, 111-129.

(3) J ohnson, K. M.; Bergmann, J . S.; Kozikowski, A. P. Cocaine and dopamine differentially protect $\left[{ }^{3} \mathrm{H}\right]$ mazindol binding sites from alkylation by $\mathrm{N}$-ethylmaleimide. Eur. J . Pharmacol., Mol. Pharmacol. Sect. 1992, 227, 411-415. 
(4) Kitayana, S.; Shimda, S.; Xu, H.; Markham, L.; Donovan, D. M.; Uhl, G. R. Dopamine transporter site-directed mutations differentially alter substrate transport and cocaine binding. Proc. Natl. Acad. Sci. U.S.A. 1992, 89, 7782-7785.

(5) Giros, B.; Wang, Y.-M.; Suter, S.; McLesky, S. B.; Pifl, C.; Caron M. C. Delineation of discrete domains for substrate, cocaine, and tricyclic antidepressant interactions using chimeric dopaminenorepinephrine transporters. J . Biol. Chem. 1994, 269, 1598515988.

(6) Clarke, R. L.; Daum, S. J .; Gambino, A. J .; Aceto, M. D.; Pearl, J .; Levitt, M.; Cumiskey, W. R.; Bogado, E. F. Compounds affecting the central nervous system. 4. $3 \beta$-Phenyltropane-2carboxylic esters and analogs. J. Med. Chem. 1973, 16, 12601267. Clarke, R. L.; Gambino, A. J .; Pierson, A. K.; Daum, S. J (2-exo-3-endo)-2-Aryltropane-3-carboxylic esters, a new class of narcotic antagonists. J. Med. Chem. 1978, 21, 1235-1242.

(7) Plati, J . T.; Ingberman, A. K.; Wenner, W. Pyrilindene Derivatives. III. Synthesis from Arecoline. J . Org. Chem. 1957, 22, 261-265.

(8) Law, H.; Leclerc, G. A.; Neumeyer, J. L. An efficient and inexpensive resolution of the potent dopaminergic substance 3-(3Hydroxyphenyl)-N-(1-propyl)-piperidine $( \pm)$-3-PPP. Tetrahe dron: Asymmetry 1991, 2, 989-992.

(9) Kozikowski, A. P : Saiah, M. K. E : J ohnson, K. M. Bergmann, J.S. Chemistry and biology of the $2 \beta$-alkyl-3 $\beta$-phenyl analogues of cocaine: subnanomolar affinity ligands that suggest a new pharmacophore model at the C-2 position. J . Med. Chem. 1995, 38, 3086-3093.

(10) Boja, J. W.; McNeil, R. M.; Lewin, A. H.; Abraham, P.; Carroll, F. I.; Kuhar, M.J. Selective dopamine transporter inhibition by cocaine analogs. Neuroreport 1992, 3, 984. Boja, J . W.; Rahman, M. A.; Philip, A.; Lewin, A. H.; Carroll, F. I.; Kuhar, M. J . Isothiocyanate derivatives of cocaine: Irreversible of ligand binding at the dopamine transporter. Mol. Pharmacol. 1991, 39, 339.
(11) Soncrant, T. T.; Raffaele, K. C.; Asthana, S.; Berardi, A.; Morris, P. P. Haxbny, J . V. Memory improvement without toxicity during chronic, low dose intravenous arecoline in Alzheimer's disease. Psychopharmacology 1993, 112, 421-427.

(12) Singh, S.; Basmadjian, G. P.; Avor, K. S.; Pouw, B.; Seale, T. W. Synthesis and ligand binding studies of 4 '-iodobenzoyl esters of tropanes and piperidines at the dopamine transporter. J . Med. Chem. 1997, 40, 2474-2481.

(13) Madras, B. K.; Fahey, M. A.; Bergman, J .; Canfield, D. R.; Spealman, R. D. Effects of cocaine and related drugs in nonhuman primates. I. [ $\left.{ }^{3} \mathrm{H}\right]$ Cocaine binding sites in caudate-putamen. J. Pharmacol. Exp. Ther. 1989, 251, 131-141.

(14) Carroll, F. I.; Lewin, A. H.; Boja, J . W.; Kuhar, M. J . Cocaine receptor: biochemical characterization and structure-activity relationships of cocaine analogs at the dopamine transporter. J. Med. Chem. 1992, 35, 969-981.

(15) Carroll, F. I.; Gao, Y.; Rahman, M. A.; Abraham, P.; Parham K.; Lewin, A. H.; Boja, J. W.; Kuhar, M. J . Synthesis, ligand binding, QSAR, and CoMFA study of $3 \beta$-(p-substituted phenyl)tropane-2 $\beta$-carboxylic acid methyl esters. J . Med. Chem. 1991 34, 2719-2725.

(16) SMART and SAINT. Data collection and processing software for the SMART system. Siemens Analytical X-ray Instruments Inc. Madison, WI, 1995.

(17) Sheldrick, G. M. SADABS, Absorption Correction Program. University of Göttingen, Germany, 1995.

(18) Sheldrick, G. M. SHELXTL PC Release 5.0 for Siemens P4 Crystal Research System. Siemens Analytical X-ray Instruments, Madison, WI, 1994.

(19) Rogers, D. On the Application of Hamilton's Ratio Test to the Assignment of Absolute Configuration and an Alternative Test. Acta Crystallogr. 1981, A37, 734-741.

J M980028+ 